\title{
Initial psychometric studies of the Emotional Self-Regulation Scale: Adult and child-youth versions
}

\author{
Estudos psicométricos iniciais da Escala de Autorregulação \\ Emocional: versões adulto e infantojuvenil
}

\author{
Ana Paula Porto NORONHA ${ }^{1}$ iD 0000-0001-6821-0299 \\ Makilim Nunes BAPTISTA ${ }^{1}$ iD 0000-0001-6519-254X \\ Helder Henrique Viana BATISTA ${ }^{1}$ (D) 0000-0001-5588-8682
}

\begin{abstract}
Emotional self-regulation is the ability to moderate attention and behaviors from different circumstances and events, and is associated to the healthy human adaptation. The present study sought for validity evidences based on the internal structure of the Adult and the Child-Youth Emotional Self-Regulation Scale and their reliability indices. The adult version was answered by 802 adults and the child-youth one was answered by 600 children and adolescents. The four-factor solution was the most adequate in both versions. The externalization of aggression (adult version) and experience evaluation (children's version) factors, and three other factors (appropriate coping strategies, pessimism and paralysis) were found with similar nomenclatures in the two scales. The reliability indices ranged between 0.69 and 0.98 (adult version) and 0.91 and 0.95 (child-youth version). In both versions, the factorial loads were higher than 0.50, explaining 62.7\% (adult version) and $64.2 \%$ (child version) of the total variance. The results are discussed in the light of the existing literature.
\end{abstract}

Keywords: Emotional states; Psychometrics; Psychological evaluation; Stress; Subjective well-being.

\section{Resumo}

A autorregulação emocional é a habilidade de moderar a atenção e os comportamentos provindos de diferentes circunstâncias e eventos e está associada à adaptação humana saudável. O presente trabalho buscou evidências de validade baseadas na estrutura interna das Escalas de Autorregulação Emocional-Adulto e Infantojuvenil e seus índices de confiabilidade. A versão adulta foi respondida por 802 adultos e a infantojuvenil por 600 crianças e adolescentes.

$\boldsymbol{\nabla} \nabla \mathbf{v}$

1 Universidade São Francisco, Programa de Pós-Graduação em Psicologia. R. Waldemar César da Silveira, 105, Jardim Cura D’Ars, 13045-510, Campinas, SP, Brasil. Correspondência para/Correspondence to: A.P.P. NORONHA. E-mail: <ana.noronha@usf.edu.br>. Support: Coordenação de Aperfeiçoamento de Pessoal de Nível Superior (Coordination for Higher Education Staff Development) (Ordinance \# 206/Financing code: 001).

Como citar este artigo/How to cite this article

Noronha, A. P. P., Baptista, M. N., \& Batista, H. H. V. (2019). Initial psychometric studies of the Emotional Self-Regulation Scale: Adult and child-youth versions. Estudos de Psicologia (Campinas), 36, e180109. http://dx.doi.org/10.1590/1982-0275201936e180109 
A solução com quatro fatores foi a mais adequada nas duas versões. Foram encontrados os fatores externalização de agressividade (versão adulto) e avaliação da experiência (versão infantojuvenil) e três fatores (estratégias de enfrentamento adequadas, pessimismo e paralisação) com nomenclaturas semelhantes nas duas escalas. Os índices de confiabilidade variaram entre 0,69 e 0,98 (versão adulto) e 0,91 e 0,95 (versão infantojuvenil). As cargas fatoriais foram superiores a 0,50, explicando 62,7\% (versão adulto) e 64,2\% (versão infantojuvenil) da variância total. Os resultados são discutidos à luz da literatura.

Palavras-chave: Estados emocionais; Psicometria; Avaliação psicológica; Estresse; Bem-estar subjetivo.

Emotional Self-Regulation (SR) has important implications for the healthy adaptation of the individual, which makes it a highly relevant subject for Psychology. Different circumstances and everyday events require people to be self-regulating, and each situation, depending on context, will require different strategies (Gross, 1998; Sheppes, Scheibe, Suri, \& Gross, 2011).

Emotional self-regulation has been understood as the ability to successfully cope with aversive emotions, and to maintain control in stressful situations involving mood disorders (Berking, Ebert, Cuijpers, \& Hofmann, 2013; Berking, Wirtz, Svaldi, \& Hofmann, 2014). In this same direction, Weiss, Gratz, and Lavender (2015) refer to it as the skill considered paramount for adaptive development in multiple domains. Previously, McKnown, Gumbiner, Russo, and Lipton (2009) have endorsed that the perspective that includes emotional SR is also the ability to moderate (inhibit, activate or change) the attention and behaviors resulting from a situation. The latter authors synthesize that SR would sustain attention, control impulses, and postpone rewards.

For Thompson (1994), the construct includes intrinsic and extrinsic processes for monitoring, evaluating and modifying emotional reactions, which was reinforced years later by Weiss et al. (2015) when considering SR as a multidimensional construct, its components being the evaluation, understanding and acceptance of emotions; the ability to control impulsive behaviors and engage in directed behaviors when negative emotions arise; and the flexible use of appropriate strategies to modulate the intensity and duration of emotional response. Gratz and Roemer (2004) share this multidimensionality and endorse that SR involves monitoring and evaluating emotional experiences, emphasizing the importance of being attentive and understanding the emotions, something that has been previously advocated by Thompson (1994). Trentacosta and Shaw (2009) also defend the idea that SR is multidimensional, however, they identify factors in distinct ways, defining them as attentional, cognitive and behavioral components that handle internal states or emotional expression.

Thus, SR has been operationalized in different ways, however, some components have been more emphasized, such as sustaining attention, controlling the impulse and delaying gratification. In this respect, SR modulates (inhibits, activates or alters) attention and behavior in response to a given stimulus (McKnown et al., 2009). Zimmer-Gembeck and Skinner (2016) argue that SR has been assumed as a coping strategy, making it possible to identify psychopathologies. As a result, it would regulate the people's actions, in harmony with their needs, motivations and life experiences.

In order to measure SR, it is necessary to consider in which phase of the life cycle the person being evaluated is, after all, in each moment of human development, different self-regulatory abilities can be developed (Bariola, Gullone, \& Hughes, 2011; Batistoni, Ordonez, Silva, Nascimento, \& Cachioni, 2013; Linhares \& Martins, 2015). The relevance of studying such phenomena is due to the important association with healthy adaptation (Briggett, Burt, Edwards, \& Deater-Deckard, 2015; Sheppes et al., 2011). For the latter authors, the different circumstances of life require the choice of strategies of emotional regulation. In addition, as proposed by Ibáñez, Ruipérez, Moya, Marqués, and Ortet (2005), SR refers to autonomy, emotional independence and the ability to actively regulate one's life in order to meet particular needs and achieve personal goals, besides engaging in healthy behaviors. There is a negative association between the construct and the vulnerability to developing diseases in healthy people, as well as the progression of diseases

2 in patients with compromised health. 
Self-regulation can attenuate neuroticism, a personality trait that is strongly associated with negative emotions (Drake, Morris, \& Davis, 2017; Tomlinson, Yousaf, Vittersø, \& Jones, 2018). Yet there has been growing evidence that a deficiency in SR is strongly associated with impulsive behaviors to regulate negative emotions (Nelis, Quoidbach, Hansenne, \& Mikolajczak, 2011; Tull, Weiss, Adams, \& Gratz, 2012) in the face of positive emotions (Weiss et al., 2015) and with a poorly adapted behavior, which includes drug use, alcohol and risky sexual behaviors (Kuvaas, Dvorak, Pearson, Lamis, \& Sargent, 2014; O'Connor \& Colder, 2015; Tull, Bardeen, DiLillo, Messman-Moore, \& Gratz, 2015).

More contemporarily, Berking et al. (2014), based on the assumption that the deficit in emotional regulation may be an important risk factor for depression, have found that a low self-regulation contributes to the development of depression, at the same time that systematic intervention based on strengthening regulation may help in the prevention and treatment of depressive symptoms. In addition, SR has been associated with mood disorders, so that children with low emotional control abilities present higher levels of depressive symptoms and lower academic performance (Zhou et al., 2015).

The findings of Weiss et al. (2015) analyzed significant and low association levels between SR, generalized expectation for negative mood regulation, and difficulty in emotional regulation and non-acceptance of emotion. Other results indicated that SR can explain levels of psychological and subjective well-being (Santana \& Godim, 2016; Simon \& Durand-Bush, 2015), as well as being a good predictor of resilience (Artuch-Garde et al., 2017). When studying a reduced version of the Self-Regulation Inventory (SRI-S), Ibañez et al. (2005) stated that SR promotes autonomy, emotional independence and the ability to regulate one's own life, in terms of acquiring goals and needs, as well as for the individual to engage in healthy behaviors. Positive actions, controllability, emotional expression, assertiveness and well-being would be the components of SR, according to the authors.

Regarding the evaluation of the construct, in addition to the SRI-S it is possible to find other instruments, especially those of self-report, in foreign literature. Also worthy of mention are the Trait Meta-Mood Scale (TMMS) (Salovey, Mayer, Goldman, Turvey, \& Palfai, 1995) and the Difficulties in Emotion Regulation Scale (DERS) (Gratz \& Roemer, 2004). On the other hand, in the Brazilian scenario, the publications on the evaluation of emotional SR are still incipient, reaffirming the importance of the present study with instruments for adult and child-youth samples, since it is necessary to develop new psychological instruments, as well as to check their psychometric parameters (Damásio \& Borsa, 2017) for each phase of human development.

On this subject, a search was made in the Coordenação de Aperfeiçoamento de Pessoal de Nível Superior (CAPES, Coordination for the Improvement of Higher Education Personnel) Periodic database to identify SR instruments for possible comparisons with the Emotional Self-Regulation Scale (Batista \& Noronha, 2018). Publications made between 2008 and 2017 were considered in the study. Some of the instruments found will be described below. The Emotion Regulation Profile (ERP), a measure of individual differences in emotion regulation, was translated and subjected to analysis of its psychometric qualities by Gondim et al. (2015). The authors applied the instrument to a sample of 686 individuals between 18 and 51 years-old. A two-factor structure was identified, one of which was to regulate negative emotions $(\alpha=0.73)$ and another to regulate positive emotions $(\alpha=0.67$ ). The correlation between the factors was 0.50 and the mean factor loads found in the factors were 0.55 (negative emotions) and 0.69 (positive emotions), which explained $40.5 \%$ of the variance.

The Portuguese version of the Tempest Self-regulation Questionnaire for Eating (TESQ-E), an SR evaluation scale for eating, was the subject of a study by Gaspar, Tomé, Simões, and Matos (2015). A total of 1200 Portuguese pre-adolescents and adolescents, aged nine to 17 years, participated in the study. The instrument had good psychometric properties and three dimensions were obtained, these being the Maintenance of healthy eating goals $(\alpha=0.86)$, the Change of meaning attributed to temptations $(\alpha=0.85)$ 
and the Reduction of temptations $(\alpha=0.81$ ). The correlations between the three dimensions varied between 0.67 and 0.76 .

Batistoni et al. (2013) investigated the psychometric indicators of the Emotional Regulation Questionnaire (ERQ), in its Brazilian version, in a sample of 153 elderly individuals. The ERQ has two factors, namely, Cognitive reassessment $(\alpha=0.75)$ and Emotional suppression $(\alpha=0.69)$, with factorial loads ranging from 0.55 to 0.83 . Still, Emotional suppression and Cognitive reassessment were positively associated $(r=0.24)$ to them.

Therefore, the present study aimed to analyze the internal structure, reliability indices and initial psychometric studies of the Emotional Self-Regulation Scale, in two versions: one for adults (EARE-AD) and another for children and adolescents (EARE-IJ). For the present study and the development of self-regulation scales, the theoretical contributions of Gratz and Roemer (2004), Thompson (1994), Berking et al. (2013), and Weiss et al. (2015) were adopted. Differently from other measures of emotional SR, both the EARE-AD and the EARE-IJ evaluate this construct by considering some situation that may generate sadness in interviewees, in order to indicate the thoughts, behaviors and feelings that best describe them in such events. In this way, there is no pre-established scenario (Gondim et al., 2015) or a specific life situation (Gaspar et al., 2015), but the participant imagines himself in an event that causes sadness in his daily life and endorses the alternatives that best describes him.

\section{Method}

\section{Participants}

The study samples were non-probabilistic for convenience. A total of 802 participants aged 18-79 (Median $[M]=27.62$, Standard Deviation $[S D]=12.19$ years) were included in the adult sample, of which 531 $(66.21 \%)$ were females. They came from three cities in the countryside of the state of São Paulo, namely, 152 (18.95\%) from the city of Campinas (SP); 318 (39.65\%) from the city of Presidente Prudente (SP) and 332 $(41.40 \%)$ from the city of Itatiba (SP). The youth sample consisted of 600 children and adolescents aged 8 to 18 ( $M=12.7, S D=2.2$ years), of which 341 (56.83\%) were females, divided into three regions of Brazil, that is, 241 (40.17\%) from the city of Passo Fundo (RS); 198 (33\%) from the city of Aracaju (SE) and, 161 $(26.83 \%)$ from the city of Itatiba (SP).

\section{Instruments}

Emotional Self-regulation Scale - Adult version (EARE-AD), and its Child-Youth version (EARE-IJ): In order to provide an instrument for the evaluation of emotional self-regulation for adults and children, the EARE-AD and the EARE-IJ were developed. These instruments aim to evaluate strategies and characteristics of the interviewee's emotional self-regulation in twelve dimensions: reorientation of attention; positive reassessment of attention; expression of emotions; learned helplessness; rumination; Impulsive reaction; savoring the present moment; capitalization; manifestation of behaviors with expression of positive emotions, accompanied by nonverbal behaviors; non-acceptance of emotional responses; difficulty in engaging in goaldirected behaviors; and lack of emotional awareness. The theory behind the development of the scales was the one by Gratz and Roemer (2004), which involves the concepts of expressive control of negative emotions and reduction of emotional arousal. Moreover, studies such as Thompson (1994), Berking et al. (2013) and 4 Weiss et al. (2015) theoretically support the scales. The items were created by the first two authors of the 
article, considering the theoretical concept described above and considering the guidelines established by the International Test Commission (2017) for the construction of items. In both EARE versions, the respondent should indicate how much his thoughts, behaviors and feelings best describe him when he is sad. Initially, the scales consisted of 83 items, arranged on a 5-point Likert scale, $0=$ never and $4=$ always, so that the highest score indicates a higher level of emotional self-regulation.

\section{Procedure}

After the approval of the project by the Research Ethics Committee, CAAE protocol number 53659716.8.0000.5514, and the signing of the Informed Consent Term, the protocols were delivered to the adult participants, collectively in classrooms of two private universities, one from Itatiba and another from Presidente Prudente (81.05\% of participants) or individually and collectively at a private university in Campinas (18.95\% of the participants). The average duration of the application was 35 minutes. The participants signed the Informed Consent Term and the protocols were delivered collectively in school classrooms, with two public schools in Passo Fundo (40.17\% of the participants), a public school in Itatiba (26.83\% of participants) and three public schools in Aracaju (33\% of participants). The collections were carried out by two Master's students and three PhD students in psychology, with previous experience in applying psychological instruments. They were carried out collectively, in classrooms with a maximum of 20 children, with a designated instructor to clarify their doubts. In the case of children up to 11 years-old, all items were read aloud and then they asked if there were any questions at the time of answering the questionnaire. For children over 11 years-old, the instrument was made available and the designated instructor assisted them in cases of doubt. The average duration of the questionnaire was 25 minutes.

\section{Data analysis}

The FACTOR software (Lorenzo-Seva \& Ferrando, 2006) was used for the analyzes. The Kaiser-MeyerOlkin (KMO) indices and the Bartlett coefficient were used to identify if the data matrices were factorizable. For the retention of factors, parallel analyzes (Timmerman \& Lorenzo-Seva, 2011), the Minimum Average Partial method (MAP) by Velicer (1976), and the Hull method (Lorenzo-Seva, Timmerman, \& Kiers, 2011) were performed. Then, factorial analyzes were conducted using the Unweighted Least Squares (ULS) method, with Promax rotation and Robust Unweighted Least Squares (RULS) to identify the indices of adjustments, namely, the Comparative Fit Index (CFI), the Root Mean Square Error of Approximation (RMSEA), the Chi-square $\left(\chi^{2}\right)$ and the Root Mean Square of Residuals (RMSR). Since the objective of the preliminary analysis was the reduction of the number of items of the scales, as retention criteria, items with a minimum factorial load of 0.50 in successive simulations, eliminating those items under this load and/or the ones that simultaneously presented loads in more than one factor. In addition, the Pearson correlation test was used to identify the associations between the factors of each scale.

\section{Results}

The results found in the EARE-AD (Bartlett $p<0.01 ; 15181.9 ; d f=561 ; \mathrm{KMO}=0.93$ ) and the EAREIJ (Bartlett $p<0.01 ; 8258.1 ; d f=378 ; \mathrm{KMO}=0.92$ ) indicated that the data matrices of the two scales were subject to factorization, and they were analyzed separately. In both, parallel analysis suggested only one factor, whereas the MAP and Hull analyzes showed, respectively, the retention of five and four factors. Initially, factorial analysis was used, limiting five, four, three, two factors and the one-way solution, in order 
to analyze which of the results would be interpretable, taking into account the literature on the construct and theoretical cohesion. The psychometric indices found in each factorial solution for the two scales are shown in Table 1.

Table 1

Psychometric indices of each factorial solution of the EARE-AD and the EARE IJ - FACTOR

\begin{tabular}{|c|c|c|c|c|c|c|c|c|}
\hline $\begin{array}{l}\text { Number of factors } \\
\text { (Number of items } \\
\text { in the final version) }\end{array}$ & $\mathrm{KMO}$ & Bartlett $(d f)$ & RMSEA & $\mathrm{CFI}$ & RMSR & $\chi^{2} / d f$ & $\begin{array}{l}\text { Explained variance } \\
\text { (reliability) }\end{array}$ & Factorial loads \\
\hline \multicolumn{9}{|c|}{ EARE-AD } \\
\hline $1(41)$ & 0.95 & $18530.2(820)$ & 0.06 & 0.983 & 0.07 & $3453.86 / 779$ & $\begin{array}{l}46.00 \% \\
(0.98)\end{array}$ & 0.51 to 0.80 \\
\hline $2(58)$ & 0.95 & 26948.9 (1653) & 0.04 & 0.986 & 0.06 & $4409.04 / 1538$ & $\begin{array}{c}48.40 \% \\
(0.98 \text { and } 0.98)\end{array}$ & 0.50 to 0.86 \\
\hline $3(49)$ & 0.95 & $23501.4(1176)$ & 0.05 & 0.992 & 0.05 & $1967.01 / 1032$ & $\begin{array}{c}55.40 \% \\
\text { (0.91 to } 0.98)\end{array}$ & 0.51 to 0.92 \\
\hline $4(34)$ & 0.93 & $15181.9(561)$ & 0.03 & 0.994 & 0.04 & $618.64 / 431$ & $\begin{array}{c}62.70 \% \\
\text { (0.69 to } 0.98)\end{array}$ & 0.51 to 0.98 \\
\hline $5(41)$ & 0.93 & $18747.7(820)$ & 0.03 & 0.996 & 0.03 & $741.97 / 625$ & $\begin{array}{c}64.40 \% \\
\text { (0.82 to } 088)\end{array}$ & 0.53 to 1.04 \\
\hline \multicolumn{9}{|c|}{ EARE-IJ } \\
\hline $1(39)$ & 0.96 & $12900.0(741)$ & 0.05 & 0.988 & 0.07 & $2060.88 / 702$ & $\begin{array}{l}46.80 \% \\
(0.99)\end{array}$ & 0.51 to 0.83 \\
\hline $2(49)$ & 0.95 & $15512.8(1176)$ & 0.04 & 0.989 & 0.06 & $2413.14 / 1079$ & $\begin{array}{c}48.10 \% \\
(0.96 \text { and } 0.99)\end{array}$ & 0.51 to 0.79 \\
\hline $3(54)$ & 0.95 & $16822.5(1431)$ & 0.04 & 0.990 & 0.05 & 2398.66/1272 & $\begin{array}{c}50.80 \% \\
\text { (0.94 to } 0.99)\end{array}$ & 0.51 to 0.79 \\
\hline $4(28)$ & 0.92 & 8265.9 (378) & 0.03 & 0.996 & 0.03 & $256.62 / 272$ & $\begin{array}{c}64.2 \% \\
\text { (0.91 to } 0.95)\end{array}$ & 0.52 to 1.01 \\
\hline $5(31)$ & 0.92 & $9361.0(465)$ & 0.02 & 0.999 & 0.03 & $259.82 / 320$ & $\begin{array}{c}67.3 \% \\
(0.56 \text { to } 0.91)\end{array}$ & 0.52 to 0.99 \\
\hline
\end{tabular}

EARE-AD: Emotional Self-Regulation Scale - Adult version; EARE-IJ: Emotional Self-Regulation Scale - Child-Youth; KMO: Kaiser-Meyer-Olkin; RMSEA: Root Mean Square Error of Approximation, RMSR: Root Mean Square of Residuals; $\chi^{2}$ : Chi-square; df: degrees of freedom; CFI: Comparative Fit Index.

The psychometric indices found were similar in all factorial solutions of the EARE-AD, with four- and five-factor solutions as the most adequate. However, the four-factor structure (CFI $=0.994, \mathrm{RMSEA}=0.03$ and $\chi^{2}=618.64, d f=431$; RMSR $=0.04$ ) showed the most coherent items in each factor and the number of factors supported by the literature. The final version consisted of 34 items, with the variance being explained, considering the four factors, of $62.7 \%$. Factor 1 accounted for $3.7 \%$; F2 accounted for $32.4 \%$; $\mathrm{F3}$, for $20.2 \%$; and F4, for $6.3 \%$. The reliability of F1 (15 items) was 0.98; F2 (7 items) presented a reliability of 0.69 ; F3 (6 items) presented a reliability of 0.88 ; and F4 (6 items), of 0.92 .

Factor 1, Appropriate coping strategies, contains items that indicate the ability to solve problems, to seek to do other things when experiencing sadness and reflection on one's own feelings (e.g., "I think about other things" and "I try to think in possible ways out of the problem"). Factor 2, Externalization of aggressiveness, has items that demonstrate irritation and aggression with things and people, as well as the accountability of the other person for what they feel ("I abuse people" and "I shout/yell" are examples of items). Factor 3 agglutinated items denoting feelings of inferiority and the negative view regarding the 6 future and was denominated Pessimism (as an example of items, "I think I'm a bad person" and "I think I'm 
worse than the others"). Finally, Factor 4 (Paralysis) has items that indicate if the respondent has appropriate actions in identifying a negative emotion or if he/she is paralyzed and thinks continuously in the situation ("I am afraid this does not happen" and "I cannot understand why I am like this"). The factor loads varied from 0.52 to 0.98 . Table 2 shows the solution of four factors with the respective factorial loads of the items, as well as the commonalities of the EARE-AD and the EARE-IJ.

The correlations found among the factors of the EARE-AD were low and moderate, ranging between 0.07 and 0.62 . Factor 1 had negative correlations with all factors, and the other correlations were positive.

Table 2

Factorial loads (> 0.50) and Commonalities (h2) of the EARE-AD and the EARE-IJ items (Loading Matrix) - FACTOR

\begin{tabular}{|c|c|c|c|c|c|c|c|c|c|c|c|}
\hline \multicolumn{6}{|c|}{ EARE-AD } & \multicolumn{6}{|c|}{ EARE-IJ } \\
\hline Item & F1 & $\mathrm{F} 2$ & F3 & F4 & $h^{2}$ & Item & F1 & $\mathrm{F} 2$ & F3 & $\mathrm{F} 4$ & $h^{2}$ \\
\hline 4 & 0.55 & -0.04 & 0.12 & -0.00 & 0.28 & 7 & -0.02 & -0.08 & 0.11 & 0.52 & 0.38 \\
\hline 12 & 0.04 & -0.03 & 0.29 & 0.55 & 0.55 & 11 & -0.03 & 0.04 & 0.16 & 0.56 & 0.46 \\
\hline 16 & 0.69 & 0.04 & 0.06 & 0.05 & 0.46 & 12 & 0.06 & 0.01 & 0.11 & 0.68 & 0.56 \\
\hline 21 & 0.04 & -0.02 & 0.13 & 0.60 & 0.45 & 13 & 0.02 & -0.06 & 0.02 & 0.71 & 0.52 \\
\hline 22 & 0.04 & -0.05 & 0.37 & 0.54 & 0.63 & 14 & 0.07 & -0.04 & 0.14 & 0.58 & 0.45 \\
\hline 27 & 0.06 & -0.01 & 0.26 & 0.51 & 0.47 & 19 & -0.11 & -0.03 & 0.61 & 0.22 & 0.67 \\
\hline 30 & -0.01 & 0.70 & 0.12 & -0.08 & 0.55 & 23 & 0.01 & -0.16 & 0.02 & 0.62 & 0.43 \\
\hline 33 & 0.69 & 0.06 & 0.05 & -0.04 & 0.47 & 26 & -0.08 & 0.13 & 0.09 & 0.62 & 0.50 \\
\hline 34 & 0.65 & -0.03 & 0.06 & 0.09 & 0.40 & 27 & -0.06 & 0.11 & 0.17 & 0.62 & 0.56 \\
\hline 37 & 0.84 & -0.02 & 0.03 & -0.01 & 0.69 & 31 & 0.01 & 0.05 & 0.66 & 0.20 & 0.63 \\
\hline 38 & 0.81 & -0.02 & 0.14 & -0.16 & 0.64 & 32 & 0.02 & 0.07 & 0.53 & 0.27 & 0.52 \\
\hline 39 & 0.85 & -0.16 & 0.06 & 0.07 & 0.72 & 33 & 0.63 & 0.14 & 0.08 & 0.03 & 0.42 \\
\hline 40 & 0.87 & -0.06 & -0.00 & 0.03 & 0.77 & 34 & 0.71 & 0.11 & 0.03 & 0.08 & 0.52 \\
\hline 41 & 0.83 & 0.03 & 0.02 & -0.10 & 0.70 & 37 & 0.73 & -0.03 & -0.06 & -0.09 & 0.59 \\
\hline 44 & 0.01 & 0.69 & 0.05 & 0.12 & 0.60 & 38 & 0.71 & -0.09 & 0.01 & -0.01 & 0.48 \\
\hline 46 & -0.05 & 0.07 & 0.06 & 0.79 & 0.76 & 39 & 0.78 & 0.02 & 0.02 & -0.02 & 0.60 \\
\hline 47 & -0.03 & -0.00 & 0.13 & 0.77 & 0.74 & 40 & 0.76 & -0.06 & -0.18 & -0.06 & 0.71 \\
\hline 51 & 0.56 & -0.00 & 0.06 & -0.05 & 0.30 & 41 & 0.75 & -0.03 & 0.05 & 0.01 & 0.52 \\
\hline 52 & -0.05 & 0.08 & 0.60 & 0.20 & 0.65 & 51 & 0.18 & -0.58 & 0.45 & 0.09 & 0.65 \\
\hline 53 & 0.01 & 0.15 & 0.86 & -0.10 & 0.78 & 52 & -0.05 & -0.06 & 0.83 & 0.03 & 0.78 \\
\hline 54 & -0.04 & 0.01 & 0.90 & 0.01 & 0.85 & 53 & 0.02 & -0.02 & 1.01 & -0.13 & 0.85 \\
\hline 55 & -0.00 & 0.02 & 0.97 & -0.09 & 0.85 & 54 & 0.00 & 0.06 & 1.00 & -0.13 & 0.82 \\
\hline 56 & 0.03 & -0.13 & 0.98 & -0.01 & 0.82 & 55 & 0.02 & 0.00 & 1.00 & -0.10 & 0.87 \\
\hline 57 & 0.07 & 0.01 & 0.71 & 0.20 & 0.69 & 56 & -0.04 & 0.09 & 0.85 & -0.01 & 0.71 \\
\hline 58 & 0.66 & 0.11 & -0.24 & 0.14 & 0.53 & 57 & 0.19 & 0.75 & 0.18 & 0.05 & 0.62 \\
\hline 60 & 0.67 & 0.03 & -0.20 & 0.05 & 0.56 & 59 & 0.24 & 0.70 & 0.08 & 0.00 & 0.59 \\
\hline 61 & 0.78 & -0.02 & -0.01 & -0.03 & 0.63 & 60 & 0.55 & 0.09 & -0.25 & 0.07 & 0.46 \\
\hline 63 & 0.67 & 0.17 & -0.20 & -0.10 & 0.58 & 63 & 0.24 & -0.68 & 0.10 & 0.07 & 0.48 \\
\hline 72 & -0.07 & 0.65 & 0.06 & 0.08 & 0.54 & & & & & & \\
\hline 76 & 0.05 & 0.70 & -0.01 & -0.05 & 0.45 & & & & & & \\
\hline 77 & 0.01 & 0.64 & -0.03 & 0.00 & 0.39 & & & & & & \\
\hline 78 & 0.03 & 0.58 & 0.11 & 0.05 & 0.45 & & & & & & \\
\hline 80 & 0.02 & 0.53 & 0.26 & -0.06 & 0.46 & & & & & & \\
\hline 83 & 0.63 & 0.01 & -0.04 & 0.06 & 0.40 & & & & & & \\
\hline
\end{tabular}

Note: The factorial loads in bold correspond to the factor that explained the items. 
In relation to the EARE-IJ, as well as in the EARE-AD, the four-factor solution was the most adequate one $\left(\mathrm{CFI}=0.996, \mathrm{RMSEA}=0.03, \chi^{2}=256.62, d f=272, \mathrm{RSMS}=0.03\right)$, given the agglutination of coherent items in each factor and the number of factors supported by the literature. Considering the final version with 28 items and four factors, the explained variance was $64.2 \%$. Factor 1 accounted for $14.9 \%$ of it, F2 for $35.9 \%$, F3 for $5.3 \%$ and F4 for $8.1 \%$. The reliability of F1 ( 8 items) was 0.95 ; F2 (4 items) had a reliability of 0.91 ; F3 (8 items), of 0.94; and F4 (8 items), of 0.94 .

Four factors were found, three of which were partially similar to those of the EARE-AD, namely, Appropriate coping strategies (Factor 1), Pessimism (Factor 3) and Paralysis (Factor 4). Factor 2, Experience evaluation, has items that indicate the respondent's assessment of the situation, that is, if the person evaluates that he/she will learn from the experience, whether the individual looks at it with optimism, if the individual

Table 3

Correlations between the factors of the EARE-AD and the EARE-IJ - FACTOR

\begin{tabular}{|c|c|c|c|c|}
\hline Factors & Coping Strategies & Externalization of Aggression & Pessimism & Paralysis \\
\hline \multicolumn{5}{|c|}{ EARE-AD } \\
\hline Externalization of Aggression & -0.07 & $x$ & & \\
\hline Pessimism & -0.32 & 0.54 & $x$ & \\
\hline Paralysis & -0.13 & 0.44 & 0.62 & $x$ \\
\hline \multicolumn{5}{|c|}{ EARE-IJ } \\
\hline Experience evaluation & 0.21 & $x$ & & \\
\hline Pessimism & -0.35 & -0.23 & $x$ & \\
\hline Paralysis & -0.14 & -0.03 & 0.65 & $x$ \\
\hline
\end{tabular}

Table 4

Structure of the Adult and Child-Youth Self-Regulation Scales

\begin{tabular}{|c|c|c|c|c|}
\hline $\begin{array}{l}\text { Number of items } \\
\text { (Number of factors) }\end{array}$ & $\begin{array}{l}\text { Factor Nomenclature } \\
\text { (Number of items) }\end{array}$ & Factor definition & Factor items & Items with inverted score \\
\hline \multicolumn{5}{|c|}{ EARE-AD } \\
\hline \multirow{4}{*}{$34(4)$} & $\begin{array}{l}\text { F1- Appropriate coping } \\
\text { strategies (15) }\end{array}$ & $\begin{array}{l}\text { Ability to solve problems, to reflect on } \\
\text { one's own feelings and to do other } \\
\text { things when experiencing sadness. }\end{array}$ & $\begin{array}{l}1,3,8,9,10,11,12 \\
13,14,18,25,26,27 \\
28 \text { and } 34\end{array}$ & - \\
\hline & $\begin{array}{l}\text { F2- Externalization of } \\
\text { Aggression (7) }\end{array}$ & $\begin{array}{l}\text { Actions that indicate anger, aggression } \\
\text { and irritation with external factors (the } \\
\text { world, objects and people), blames other } \\
\text { people for what he feels. }\end{array}$ & $\begin{array}{l}7,15,29,30,31,32 \\
\text { and } 33 .\end{array}$ & $\begin{array}{l}7,15,29,30,31,32 \\
\text { and } 33 .\end{array}$ \\
\hline & F3- Pessimism (6) & $\begin{array}{l}\text { Negative vision of the future, feelings of } \\
\text { inferiority when experiencing sadness. }\end{array}$ & $\begin{array}{l}19,20,21,22,23 \\
\text { and } 24 .\end{array}$ & $19,20,21,22,23$ and 24. \\
\hline & F4- Paralysis (6) & $\begin{array}{l}\text { Finding appropriate solutions by } \\
\text { experiencing negative emotions or } \\
\text { staying paralyzed, continuously thinking } \\
\text { about the situation. }\end{array}$ & $2,4,5,6,16$ and 17. & $2,4,5,6,16$ and 17. \\
\hline \multicolumn{5}{|c|}{ EARE-IJ } \\
\hline \multirow{4}{*}{$28(4)$} & $\begin{array}{l}\text { F1- Appropriate coping } \\
\text { strategies (8) }\end{array}$ & Same as the EARE-AD. & $\begin{array}{l}12,13,14,15,16,17 \\
18 \text { and } 27 .\end{array}$ & - \\
\hline & $\begin{array}{l}\text { F2- Experience } \\
\text { evaluation (8) }\end{array}$ & $\begin{array}{l}\text { Feeling able to solve problems, and } \\
\text { extracting something good when } \\
\text { experiencing sadness. }\end{array}$ & $19,25,26$ and 28. & 25 and 26. \\
\hline & F3- Pessimism (8) & Same as the EARE-AD. & $\begin{array}{l}6,10,11,20,21,22, \\
23 \text { and } 24 .\end{array}$ & $\begin{array}{l}6,10,11,20,21,22,23 \\
\text { and } 24 .\end{array}$ \\
\hline & F4- Paralysis (4) & Same as the EARE-AD. & $1,2,3,4,5,7,8$ and 9 & $1,2,3,4,5,7,8$ and 9 . \\
\hline
\end{tabular}


feels able to solve the problems ("I think I can solve the problem" and "I cannot enjoy good things that are happening" are examples of items). The factorial loads ranged from 0.52 to 1.01 , as shown in Table 2.

As for the correlations between the factors, it was possible to identify positive and negative coefficients and low to high associations of magnitudes, with values between -0.03 and 0.65 . Both F1 and F2 presented positive associations between themselves and negative associations with F3 and F4. In turn, F3 and F4 were positively associated. Table 3 indicates the correlations found for both the EARE-AD and the EARE-IJ.

It should be noted that some items from the EARE-AD and the EARE-IJ should have their scores inverted. Table 4 shows a synthesis of the results found in the present study regarding the structure of the scales (number of items and factors, definition of factors, present items and each factor, and which of these items need to be inverted).

\section{Discussion}

The objective of the present study was to verify the internal structure of both the EARE-AD and the EARE-IJ in samples of Brazilian volunteers, adults and children respectively. In addition, it should be emphasized that the study is preliminary, with further data collection to be carried out in order to deepen and refine the scales. Factor analysis indicated results similar to those initially proposed by Gratz and Roemer (2004), with a four-factor structure for assessing emotional self-regulation.

Of the four factors found in the two scales, three presented the same nomenclatures and definitions in both the adult and youth versions, namely, appropriate coping strategies, pessimism and paralysis. Of these, one refers to the control of negative feelings (pessimism) and the other two factors refer to the control of impulsive behaviors and negative thoughts (appropriate coping strategies and paralysis). In addition, in the EARE-AD, one factor is related to the control of impulsive behaviors (externalization of aggressiveness) and in the EARE-IJ, another factor refers to the control of negative feelings and thoughts (experience evaluation). The findings differed from those found by Gondim et al. (2015) in the ERP, in which two factors were obtained (positive and negative emotions). It should be noted that such results can be explained by the fact that the ERP authors have sought to access respondents' emotions through eliciting scenarios, while both EAREs are self-report measures, indicating differences in the construction and response of the instruments.

The two versions of the Emotional Self-Regulation Scale presented factorial loads similar to those of other studies that used measures of emotional regulation (Batistoni et al., 2013; Gondim et al., 2015). However, the factor loadings of both the EARE-AD and the EARE-IJ were higher, as were the total variance explained and the reliability levels, possibly because the EARE-AD and the EARE-IJ assessed emotional control in the face of negative events and that may lead to impulsive behaviors, negative feelings and thoughts, that is, they are more specific than other instruments that evaluate emotions (Gondim et al., 2015) or are focused on life situations such as eating (TESQ- E, Gaspar et al., 2015).

In addition, the adjustment indices of the model were adequate to the data in the two scales of emotional self-regulation, however, factorial loads with values above 0.90 were observed in both scales, which may indicate the existence of improper solutions, which are called Heywood cases (Kolenikov \& Bollen, 2012; Wang \& Parmigiani, 2017). Improper solutions relate to situations where the estimates assume values that are impossible for the corresponding parameters or that are restricted to the limits of possible values, in this case, limited to zero or negative error variances. These data may indicate errors in the model, the data or the estimator (Wang \& Parmigiani, 2017). Kolenikov and Bollen (2012) have suggested that negative error variations can occur frequently. One of the possibilities would be to consider that some items with semantic similarities need to be eliminated in the analysis with new samples in order to minimize possible improper solutions. 
Regarding the EARE-AD, low-magnitude and negative correlations were found between the appropriate coping strategies factor and the other three factors, possibly because it is a factor that indicates positive thoughts and attitudes in the face of sadness, whereas the other factors refer to the control of negative actions, thoughts and feelings in the face of the same sad events (Zimmer-Gembeck \& Skinner, 2016). Even with low magnitude correlations, some values were higher than those found by other authors (Batistoni et al., 2013; Gratz \& Roemer, 2004). Finally, the moderate correlations were positive and were in the same direction as those found in other studies with measures of emotional self-regulation (Gondim et al., 2015; Gratz \& Roemer, 2004; Nelis et al., 2011).

The correlations found between the EARE-IJ factors indicated two positive factors (appropriate coping strategies and experience evaluation) and two negative factors (paralysis and pessimism). Positive factors indicate attitudes, thoughts, and control of negative feelings in the face of sadness. Negative factors, on the other hand, refer to the control of negative feelings and thoughts when experiencing sad events. The associations found were positive between the same pole, and negative when they were of different poles, which indicates similarity with the results found in the EARE-AD, with the difference that the EARE-IJ had two negative and two positive factors, and the EARE-AD had three negative and one positive factors (ZimmerGembeck \& Skinner, 2016). In addition, the results found in the EARE-IJ are similar to what other authors found for SR instruments (Gondim et al., 2015; Gratz \& Roemer, 2004; Nelis et al., 2011), with higher magnitudes (Batistoni et al., 2013; Gratz \& Roemer, 2004).

The EARE-AD has a factor that evaluates positive behaviors and thoughts in the face of sad events (appropriate coping strategies), and the EARE-IJ has two factors that also evaluate behaviors and positive thoughts in the face of sad events (coping strategies and experience evaluation). Nevertheless, both are measures that evaluate only the control of negative emotions. Weiss et al. (2015) argue that the control of positive emotions is also necessary, since individuals who fail to do so tend to be more distracted in their activities and do not discriminate correctly the received information, which carries along a greater risk of making inappropriate decisions (Nelis et al., 2011; Tull et al., 2012). Still, those who manage to control positive emotions tend to have higher levels of self-esteem, life satisfaction, and resilience (Artuch-Garde et al., 2017). However, by focusing on only one type of emotion (sadness), the Emotional Self-Regulation Scale may offer a greater explained variance and be more focal than the other ones that assess several positive affects, and may also be useful in populations with mood dysphoria and/or disorder (Berking et al., 2013).

\section{Conclusion}

The psychometric indices of the EARE-AD and the EARE-IJ were satisfactory, according to the objective of this study. Regarding limitations, the scope did not allow additional analyzes to be carried out, for example, the one concerning the discriminative power of the items and if the Heywood effect will be maintained in analyzes with new samples. It is believed that such verifications would allow the elimination of items with correlations of strong magnitudes between them, that is, the possibility of item reduction. As an agenda for future research, it is suggested that the construct be investigated considering its relationship with other instruments that evaluate, for example, anxiety and depression, besides considering other positive constructs, such as self-esteem, character strengths, perception of family support and parental styles, in order to obtain evidence of validity to contribute to evaluative processes in the various contexts.

\section{Contributors}

A. P. P. NORONHA and M. N. BAPTISTA were responsible for the conception and design of this study. All the three 


\section{References}

Artuch-Garde R, González-Torres, M. C., La Fuente, J., Vera, M. M., Fernández-Cabezas, M., \& López-García, M. (2017). Relationship between resilience and self-regulation: A study of Spanish youth at risk of social exclusion. Frontiers in Psychology, 8(612), 1-11. http://dx.doi.org/10.3389/fpsyg.2017.00612

Bariola, E., Gullone, E., \& Hughes, E. K. (2011). Child and adolescent emotion regulation: The role of parental emotion regulation and expression. Clinical Child and Family Psychology Review, 14(2), 198-212. http://dx doi.org/10.1007/ s10567-011-0092-5

Batista, H. H. V., \& Noronha, A. P. P. (2018). Instrumentos de autorregulação emocional: uma revisão de literatura. Avaliação Psicológica, 17(3), 389-398. http://dx.doi.org/10.15689/ap.2018.1703.15643.12

Batistoni, S. S. T., Ordonez, T. N., Silva, T. B. L., Nascimento, P. P. P., \& Cachioni, M. (2013). Emotional Regulation Questionnaire (ERQ): indicadores psicométricos e relações com medidas afetivas em amostra idosa. Psicologia: Reflexão e Crítica, 26(1), 10-18. http://dx.doi.org/10.1590/\$0102-79722013000100002

Berking, M., Ebert, D., Cuijpers, P., \& Hofmann, S. G. (2013). Emotion-regulation skills training enhances the efficacy of cognitive behavioral therapy for major depressive disorder. Psychotherapy and Psychosomatics, 82(4), 234-245. http://dx.doi.org/10.1159/000348448

Berking, M., Wirtz, C. M., Svaldi, J., \& Hofmann, S. G. (2014). Emotion regulation predicts symptoms of depression over five years. Behavior Research and Therapy, 57(1), 13-20. http://dx.doi.org/10.1016/j.brat.2014.03.003

Bridgett, D. J., Burt, N. M., Edwards, E. S., \& Deater-Deckard, K. (2015). Intergenerational transmission of self-regulation: A multidisciplinary review and integrative conceptual framework. Psychological Bulletin, 141(3), 602-654. http:// dx.doi.org/10.1037/a0038662

Damásio, B. F., \& Borsa, J. C. (2017). Manual de desenvolvimento de instrumentos psicológicos. São Paulo: Vetor.

Drake, M. M, Morris, M., \& Davis, T. J. (2017). Neuroticism's susceptibility to distress: Moderated with mindfulness. Personality and Individual Differences, 106(1), 248-252. http://dx.doi.org/10.1016/j.paid.2016.10.060

Gaspar, T., Tomé, G. Q., Simões, C., \& Matos, M. G. (2015). Estratégias de auto-regulação em pré-adolescentes e adolescentes: versão portuguesa do TESQ-E. Psicologia: Reflexão e Crítica, 28(4), 649-658. http://dx.doi. org/10.1590/1678-7153.201528402

Gondim, S. M. G., Pereira, C. R., Hirschle, A. L. T., Palma, E. M. S., Alberton, G. D., Paranhos, J., ... Ribeiro, W. R. B. (2015). Evidências de validação de uma medida de características pessoais de regulação de emoções. Psicologia: Reflexão e Crítica, 28(4), 659-667. http://dx.doi.org/10.1590/1678-7153.201528403

Gratz, K. L., \& Roemer, L. (2004). Multidimensional assessment of emotion regulation and dysregulation: Development factor structure, and initial validation of the Difficulties in Emotion Regulation Scale. Journal of Psychopathology and Behavioral Assessment, 26(1), 41-54.http://dx.doi.org/10.1023/B:JOBA.0000007455.08539.94

Gross, J. J. (1998). The emerging field of emotion regulation: An integrative review. Review of General Psychology 2(3), 271-299. http://dx.doi.org/10.1037/1089-2680.2.3.271

Ibañez, M. J., Ruipérez, M. A., Moya, J., Marqués, M. J., \& Ortet, G. (2005). A short version of the Self-Regulation Inventory (SRI-S). Personality and Individual Differences, 39(6), 1055-1059. http://dx.doi.org/10.1016/j.paid.2005.02.029

International Test Commission. (2017). The ITC Guidelines for translating and adapting tests (Second edition). Retrieved December 8, 2017, from https://www.intestcom.org/files/guideline_test_adaptation_2ed.pdf

Kolenikov, S., \& Bollen, K. A. (2012). Testing negative error variances: Is a Heywood Case a symptom of misspecification? Sociological Methods \& Research, 41(1), 124-167. http://dx.doi.org/10.1177/0049124112442138

Kuvaas, N. J., Dvorak, R. D., Pearson, M. R., Lamis, D. A., \& Sargent. E. M. (2014). Self-regulation and alcohol use involvement: A latent class analysis. Addictive Behaviors, 39(1), 146-152. http://dx.doi.org/ 10.1016/j.addbeh.2013.09.020

Linhares, M. B. M, \& Martins, C. B. S. (2015). O processo da autorregulação no desenvolvimento de crianças. Estudos de Psicologia (Campinas), 32(2), 281-293. http://dx.doi.org/10.1590/0103-166X2015000200012

Lorenzo-Seva, U. \& Ferrando, P. J. (2006). FACTOR: A computer program to fit the exploratory factor analysis model. Behavior Research Methods, 38(1), 88-91. http://dx.doi.org/10.3758/BF03192753

Lorenzo-Seva, U., Timmerman, M. E., \& Kiers, H. A. (2011). The hull method for selecting the number of common factors. Multivariate Behavioral Research, 46(2), 340-364. http://dx.doi.org/10.1080/00273171.2011.564527

McKnown, C., Gumbiner, L. M., Russo, N. M., \& Lipton, M. (2009). Social-emotional learning skill, self-regulation, and social competence in typically developing and clinic-referred children. Journal of Clinical Child \& Adolescence Psychology, 38(6), 858-871. http://dx.doi.org/10.1080/15374410903258934 
Nelis, D., Quoidbach, J., Hansenne, M., \& Mikolajczak, M. (2011). Measuring individual differences in emotion regulation: The Emotion Regulation Profile-Revised (ERP-R). Psychologica Belgica, 51(1), 49-91. http://dx.doi.org/10.5334/pb-51$1-49$

O'Connor, R. M., \& Colder, C. R. (2015). The Prospective Joint Effects of Self-Regulation and Impulsive Processes on Early Adolescence Alcohol Use. Journal of Studies on Alcohol and Drugs, 76(6), 884-894. http://dx.doi.org/10.15288/ jsad.2015.76.884

Salovey, P., Mayer, J. D., Goldman, S. L., Turvey, C., \& Palfai, T. P. (1995). Emotional attention, clarity and repair: Exploring emotional intelligence using the Trait Meta-mood Scale. In J. W. Pennebaker (Ed.), Emotion disclosure and health (pp. 125-154). Washington: APA Books.

Santana, V. S., \& Gondim, S. M. G. (2016). Regulação emocional, bem-estar psicológico e bem-estar subjetivo. Estudos de Psicologia (Natal), 21(1), 58-68. http://dx.doi.org/10.5935/1678-4669.20160007

Sheppes, G., Scheibe, S., Suri, G., \& Gross, J. J. (2011). Emotion-regulation choice. Psychological Science, 22(11), 1391-1396. http://dx.doi.org/10.1177/0956797611418350

Simon, C.R., \& Durand-Bush, N. (2015). Does self-regulation capacity predict psychological well-being in physicians? Psychology, Health and Medicine, 20(3), 311-321. http://dx.doi.org/10.1080/13548506.2014.936887

Thompson, R. A. (1994). Emotion regulation: A theme in search of definition. Monographs of the Society for Research in Child Development, 59(2-3), 25-52. http://dx.doi.org/10.1111/j.1540-5834.1994.tb01276.x

Timmerman, M. E., \& Lorenzo-Seva, U. (2011). Dimensionality assessment of ordered polytomous items with parallel analysis. Psychological Methods, 16(2), 209-220. http://dx.doi.org/ 10.1037/a0023353

Tomlinson, E. R., Yousaf, O., Vittersø, A. D., \& Jones, L. (2018). Dispositional mindfulness and psychological health: A systematic review. Mindfulness, 9(2), 23-43. http://dx.doi.org/10.1007/s12671-017-0762-6

Trentacosta, C. J., \& Shaw, D. S. (2009). Emotional self-regulation, peer rejection, and antisocial behavior: Developmental associations from early childhood to early adolescence. Journal of Applied Developmental Psychology, 30(3), 356-365. http://dx.doi.org/ 10.1016/j.appdev.2008.12.016

Tull, M. T., Bardeen, J. R., DiLillo, D., Messman-Moore, T., \& Gratz, K. L. (2015). A prospective investigation of emotion dysregulation as a moderator of the relation between posttraumatic stress symptoms and substance use severity. Journal of Anxiety Disorders, 29, 52-60. http://dx.doi.org/10.1016/j.janxdis.2014.11.003

Tull, M. T., Weiss, N. H., Adams, C. E., \& Gratz, K. L. (2012). The contribution of emotion regulation difficulties to risky sexual behavior within a sample patients in residential substance abuse treatment. Addictive Behaviors, 37(10), 1084-1092. http://dx.doi.org/ 10.1016/j.addbeh.2012.05.001

Velicer, W. F. (1976). Determining the number of components from the matrix of partial correlations. Psychometrika, 41(3), 321-327. http://dx.doi.org/10.1007/BF02293557

Wang, X. V., \& Parmigiani, G. (2017). Integrative factor analysis: An unsupervised method for quantifying cross-study consistency of gene expression data. Geromics, 110(2), 80-88. http://dx.doi.org/10.1016/j.ygeno.2017.08.009

Weiss, N. H., Gratz, K. L., \& Lavender, J. M. (2015). Factor structure and initial validation of a multidimensional measure of difficulties in the regulation of positive emotions: The DERS-Positive. Behavior Modification, 39(3), 431-453. http:// dx.doi.org/10.1177/0145445514566504

Zhou, Y, Bullock, A., Liu, J., Fu, R., Coplan, R. J., \& Cheah, C. S. L. (2015). Validation of the self-regulation scale in Chinese children. Journal of Psychoeducational Assessment, 34(6), 1-6. http://dx.doi.org/10.1177/0734282915622853

Zimmer-Gembeck, M. J., \& Skinner, E. A. (2016). The development of coping: Implications for psychopathology and resilience. In D. Cicchetti (Ed.), Developmental psychopathology: Risk, resilience, and intervention (pp. 485-545). Hoboken: John Wiley \& Sons. http://dx.doi.org/10.1002/9781119125556.devpsy410

Received: October 1, 2018

Final version: June 3, 2019

Approved: June 11, 2019 